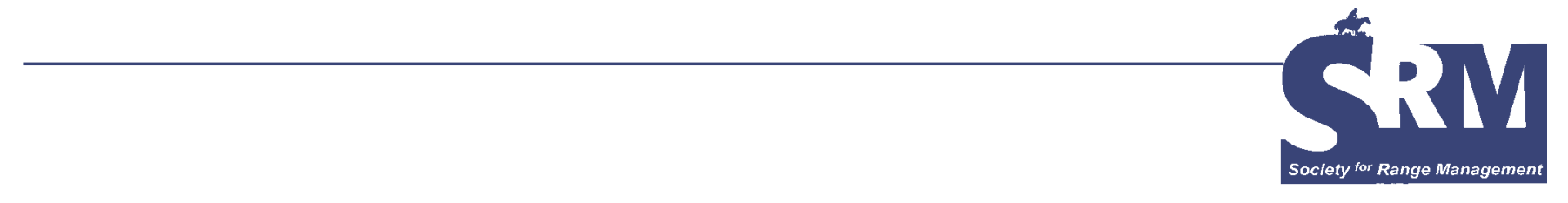

\title{
Lupine-Induced Crooked Calf Disease: The Last 20 Years
}

\author{
By Stephen T. Lee, Kip E. Panter, Clive C. Gay, \\ James A. Pfister, Michael H. Ralphs, Dale R. Gardner, \\ Bryan L. Stegelmeier, Ernie S. Motteram, Daniel Cook, \\ Kevin D. Welch, Benedict T. Green, and T. Zane Davis
}

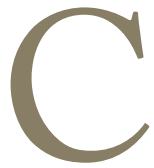

rooked calf disease was first reported in the late 1950s and early 1960s. ${ }^{1-3}$ While lupine (Lupinus spp.) was suspected as the cause in some of these cases, it was not until the mid-1960s that lupine was confirmed as the direct cause of crooked calf syndrome. ${ }^{4,5}$ The term "crooked calf disease" is used to describe a number of skeletal malformations in newborn calves, including a twisted spine, neck, and one or both forelimbs (Fig. 1). Occasionally, distortion of the rear legs also occurs. These deformities may be so severe that calves are unable to stand or follow their mothers. Many slightly to moderately affected calves fail to survive after birth and severely affected calves that are born live are typically destroyed because they cannot stand, walk, and nurse. ${ }^{4-6}$

Cleft palate has also been identified as part of the syndrome (Fig. 2), although the occurrence is less frequent than skeletal malformations. ${ }^{7,8}$ Cleft palate often results in calf death due to aspiration of milk or rumen liquor into the lungs causing pneumonia, and for survivors, an inability to graze normally from forage compaction into the cleft. ${ }^{9}$

The difficulty in associating lupine consumption with these congenital, or birth, defects is that the exposure occurs during the first stages of pregnancy. Early studies suggested that most of the skeletal malformations develop when the pregnant cow eats toxic lupines $40-70 \mathrm{~d}$ after conception. ${ }^{4,5}$ More recent work indicates that the developing fetuses are susceptible up to $100 \mathrm{~d}$ following conception. ${ }^{10}$ The cleft palate is induced during a much narrower period of the 40-50th day of pregnancy. ${ }^{8}$ Cows pregnant with severely

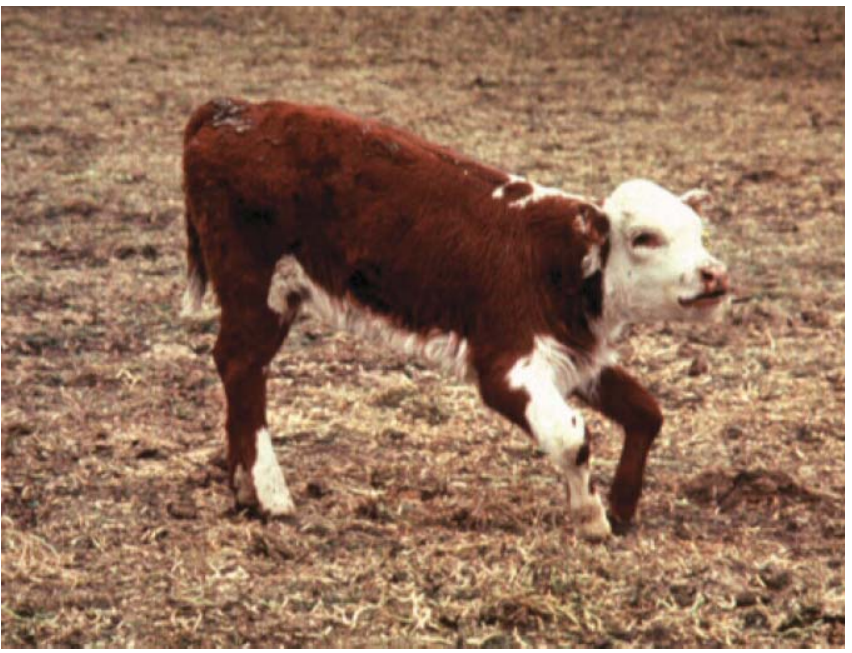

Figure 1. Lupine-induced crooked calf.

deformed calves often experience difficult births and require caesarian section or veterinarian assistance for delivery. ${ }^{10,11}$

Teratogens are agents that alter normal development of the fetus. One group of chemical compounds that can be physiologically active are called alkaloids. Within this group a class of chemical compounds called quinolizidine alkaloids were suspected of being the teratogenic toxins. But the specific teratogen, the alkaloid anagyrine, was not identified in suspect lupines until the 1970s (Table 1). ${ }^{12}$ Continued research by Keeler and others further determined that 


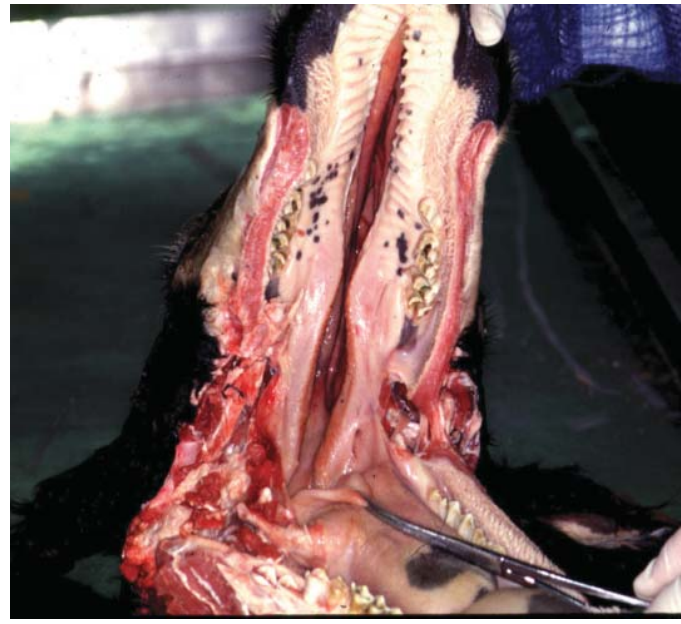

Figure 2. Cleft palate from lupine-induced crooked calf.

Table 1. Common and scientific names of lupines

\begin{tabular}{|l|l|}
\hline Common name & Scientific name \\
\hline Velvet lupine & Lupinus leucophyllus \\
\hline Sulphur lupine & Lupinus sulphureus \\
\hline Silky lupine & Lupinus sericeus \\
\hline Silvery lupine & Lupinus argenteus \\
\hline
\end{tabular}

another class of alkaloids (piperidine, including ammodendrine; and $N$-methyl ammodendrine) found in relatively few lupine species, were also teratogenic, and caused the same skeletal defects as anagyrine. ${ }^{11}$ Using ultrasound imaging, researchers determined that the teratogenic alkaloids reduced fetal movement during the critical stage of pregnancy: when the fetus is rapidly growing and normal fetal activity is essential for normal skeletal development.,13 This lack of fetal movement is responsible for the skeletal malformations, as the limbs are essentially "frozen" in a crooked state from lack of movement. Cleft palates form as the tongue remains pressed into the open, developing palate and blocks normal closure. ${ }^{6,13}$

Research has shown that anagyrine concentrations in many lupines increase during flowering and peak during the seed pod stage, and then decline to low levels as the seed pods shatter. ${ }^{14-16}$ Lupine species are legumes, and therefore, though toxic, are highly nutritious and typically contain $>16 \%$ crude protein in the vegetative parts and approximately $40 \%$ crude protein in the seeds. ${ }^{17}$ "Sweet lupines" (i.e., alkaloidfree varieties) are cultivated for their nutritional benefits for animal and human food worldwide. Even though we now know the alkaloid composition of many lupine species, and how these toxins affect the developing fetus, large livestock losses continue to occur on rangelands of western North America.
In this report, we document reported incidences of crooked calf disease and provide information to help ranchers that have toxic lupine species make informed breeding and grazing management decisions. One location with significant numbers of crooked calves is discussed in detail below, while the majority of cases are briefly summarized in Table 2. Figure 3 is a map of the northwestern United States and shows the counties in which major crooked calf incidents have been reported to our research team during the last $20 \mathrm{yr}$. There are undoubtedly many other incidents that went unreported.

\section{Adams County, Washington (Location 1; Table 2), 1997-Ongoing}

Lupines are part of nearly all rangelands in Adams County in east-central Washington State. A significant proportion of this and adjacent counties are topographically referred to as the Channeled Scablands (lat $46^{\circ} \mathrm{N}$, long $118^{\circ} \mathrm{W}$ ). This landscape was created by geologic glacial floods ${ }^{18}$ that removed most of the topsoil, thus creating a region with poor soils that is best utilized by grazing cattle. Today rangelands in this area are dominated by annual grasses and forbs, particularly cheatgrass (Bromus tectorum). Lupines also grow abundantly in this area when precipitation is favorable; the predominant species are velvet lupine, silky lupine, and sulphur lupine. ${ }^{15,16}$ Figure 4 is a photograph of rangeland in Adams County, Washington, showing velvet lupine in full flower. In the Cow Creek drainage of Adams County, Washington, ranchers consider a 1-5\% incidence of crooked calf disease to be acceptable and this degree of calf losses is considered the "cost of doing business." ${ }^{19,20}$ However, in some years, such as 1980 to 1985 and in 1991, individual ranches experienced a much larger incidence of crooked calf disease; in some cases, as high as $25 \%$ of calves born were affected. In 1997 there was a catastrophic outbreak of crooked calf disease involving virtually all ranches with velvet lupine on their rangeland. Between 3,000 and 4,000 calves were born with skeletal defects, most of which were so severe that the calves had to be destroyed. During that year, thirteen specific ranches were surveyed with calf losses ranging from $0 \%$ to $100 \%$. Specifically, 628 of 2,210 calves born on these 13 ranches were severely deformed and had to be destroyed. ${ }^{19,20} \mathrm{~A}$ significant but unknown number of less severely affected calves were saved as they were able to nurse and graze. Though these calves did provide some financial benefit to the ranchers, they had reduced growth rates and did not reach their full economic potential.

The three lupine species thought responsible for these losses were identified as velvet lupine, sulphur lupine, and silky lupine. Chemical analysis revealed that velvet lupine and sulphur lupine contained the teratogens anagyrine and ammodendrine, respectively, while silky lupine did not contain any known teratogens. ${ }^{21}$ Research during the last $6 \mathrm{yr}$ has implicated velvet lupine as the toxic lupine species in Adams County, Washington, most responsible for lupine-induced crooked calf disease. 
Table 2. Reported incidences of crooked calf disease

\begin{tabular}{|c|c|c|c|c|c|c|}
\hline Location ${ }^{a}$ & Year & $\begin{array}{l}\text { No. of } \\
\text { cows }\end{array}$ & $\begin{array}{c}\% \\
\text { deformed } \\
\text { calves }\end{array}$ & $\begin{array}{l}\text { Management } \\
\text { factors initiating } \\
\text { poisoning }\end{array}$ & $\begin{array}{l}\text { Lupine(s) } \\
\text { present }\end{array}$ & Solution(s) ${ }^{b}$ \\
\hline $\begin{array}{l}\text { Lincoln } \\
\text { County, } \\
\text { WA (2) }\end{array}$ & $1999-2003$ & $38-45$ & $16-82$ & $\begin{array}{l}\text { Spring calving; changed } \\
\text { calving date by } 1 \mathrm{mo} \text {, } \\
\text { increased lupine } \\
\text { consumption }\end{array}$ & $\begin{array}{l}\text { Velvet and } \\
\text { sulphur }\end{array}$ & $\begin{array}{l}\text { Adjust grazing to avoid } \\
\text { lupine consumption } \\
\text { during critical period }\end{array}$ \\
\hline $\begin{array}{l}\text { Stevens } \\
\text { County, } \\
\text { WA (3) }\end{array}$ & 2004 & 115 & 5 & $\begin{array}{l}\text { Changed calving date } \\
\text { from February to January; } \\
\text { lupine available during } \\
\text { susceptible period }\end{array}$ & $\begin{array}{l}\text { Velvet and } \\
\text { silky }\end{array}$ & $\begin{array}{l}\text { Change to later calving } \\
\text { date }\end{array}$ \\
\hline $\begin{array}{l}\text { Spokane } \\
\text { County, } \\
\text { WA (4) }\end{array}$ & $2002-2003$ & 20 & $10-20$ & $\begin{array}{l}\text { Cattle given access to } \\
\text { lupine during susceptible } \\
\text { period }\end{array}$ & $\begin{array}{l}\text { Lupine } \\
\text { present; not } \\
\text { identified }\end{array}$ & $\begin{array}{l}\text { Graze lupine-free } \\
\text { pastures during critical } \\
\text { period }\end{array}$ \\
\hline $\begin{array}{l}\text { Whitman } \\
\text { County, } \\
\text { WA (5) }\end{array}$ & 1999 & 18 & 11 & $\begin{array}{l}\text { Cattle given access to } \\
\text { lupine during susceptible } \\
\text { period }\end{array}$ & Velvet & $\begin{array}{l}\text { Graze lupine-free } \\
\text { pastures during critical } \\
\text { period }\end{array}$ \\
\hline $\begin{array}{l}\text { Franklin } \\
\text { County, } \\
\text { WA (6) }\end{array}$ & 1997 & 25 & 100 & $\begin{array}{l}\text { Velvet lupine the major } \\
\text { forage species during } \\
\text { susceptible period }\end{array}$ & Velvet & $\begin{array}{l}\text { Graze lupine-free } \\
\text { pastures during critical } \\
\text { period, or change } \\
\text { calving date }\end{array}$ \\
\hline $\begin{array}{l}\text { Walla } \\
\text { Walla } \\
\text { County, } \\
\text { WA (7) }\end{array}$ & 2003 & $\begin{array}{l}13 \\
\text { heifers; } \\
22 \text { adult } \\
\text { cows }\end{array}$ & $\begin{array}{l}30 \text { for } \\
\text { heifers; } \\
0 \text { for cows }\end{array}$ & $\begin{array}{l}\text { Heifers exposed to } \\
\text { lupine during critical } \\
\text { period; cows exposed } \\
\text { after critical period of } \\
\text { gestation }\end{array}$ & $\begin{array}{l}\text { Velvet, } \\
\text { sulphur, } \\
\text { and silky }\end{array}$ & $\begin{array}{l}\text { Cows exposed to } \\
\text { lupine after critical } \\
\text { gestation period }\end{array}$ \\
\hline $\begin{array}{l}\text { Umatilla } \\
\text { County, } \\
\text { OR (8) }\end{array}$ & $1991-1992$ & 131 & 51 & $\begin{array}{l}\text { Cows exposed to toxic } \\
\text { sulphur lupine during } \\
\text { critical period; weather } \\
\text { caused lupine to mature } \\
\text { early; cows eating seed } \\
\text { pods were affected }\end{array}$ & $\begin{array}{l}\text { Sulphur and } \\
\text { velvet }\end{array}$ & $\begin{array}{l}\text { Monitor lupine growth; } \\
\text { adjust grazing to avoid } \\
\text { lupine consumption } \\
\text { during critical period }\end{array}$ \\
\hline $\begin{array}{l}\text { Gem } \\
\text { County, ID } \\
\text { (9) }\end{array}$ & 2004 & $\begin{array}{l}200 \\
\text { heifers }\end{array}$ & 18 & $\begin{array}{l}\text { Heifers exposed to } \\
\text { lupine during critical } \\
\text { period }\end{array}$ & $\begin{array}{l}\text { Lupine } \\
\text { present; not } \\
\text { identified }\end{array}$ & $\begin{array}{l}\text { Graze lupine-free } \\
\text { pastures during critical } \\
\text { period, or change } \\
\text { calving date }\end{array}$ \\
\hline $\begin{array}{l}\text { Clark } \\
\text { County, ID } \\
\text { (10) }\end{array}$ & 2001 & 52 & 36 & $\begin{array}{l}\text { Heifers exposed to } \\
\text { lupine during critical } \\
\text { period }\end{array}$ & $\begin{array}{l}\text { Purple } \\
\text { lupine; not } \\
\text { identified }\end{array}$ & $\begin{array}{l}\text { Producer changed } \\
\text { calving date and } \\
\text { reduced incidence } \\
\text { to }<2 \%\end{array}$ \\
\hline $\begin{array}{l}\text { Caribou } \\
\text { County, ID } \\
\text { (11) }\end{array}$ & 2001 & 135 & 21 & $\begin{array}{l}\text { Cattle exposed to lupine } \\
\text { during critical period }\end{array}$ & $\begin{array}{l}\text { Lupine } \\
\text { present; not } \\
\text { identified }\end{array}$ & $\begin{array}{l}\text { Producer no longer } \\
\text { uses this pasture for } \\
\text { pregnant cows }\end{array}$ \\
\hline $\begin{array}{l}\text { Caribou } \\
\text { County, ID } \\
\text { (11) }\end{array}$ & 2003 & 80 & 75 & $\begin{array}{l}\text { Heifers synchronized } \\
\text { during breeding and } \\
\text { exposed during critical } \\
\text { period; severity of } \\
\text { deformities varied (see } \\
\text { Fig. 5) }\end{array}$ & $\begin{array}{l}\text { Lupine } \\
\text { present; not } \\
\text { identified }\end{array}$ & $\begin{array}{l}\text { Change grazing to } \\
\text { reduce exposure during } \\
\text { critical period }\end{array}$ \\
\hline $\begin{array}{l}\text { Jefferson } \\
\text { County, } \\
\text { MT (12) }\end{array}$ & Ongoing & 200 & 1 & $\begin{array}{l}\text { Some calf deformities } \\
\text { from exposure to lupine } \\
\text { during gestation }\end{array}$ & $\begin{array}{l}\text { Lupine } \\
\text { present; not } \\
\text { identified }\end{array}$ & $\begin{array}{l}\text { Current risk and losses } \\
\text { are acceptable to } \\
\text { rancher }\end{array}$ \\
\hline
\end{tabular}




\section{Table 2. Continued}

\begin{tabular}{|c|c|c|c|c|c|c|}
\hline Locationa & Year & $\begin{array}{l}\text { No. of } \\
\text { cows }\end{array}$ & $\begin{array}{c}\% \\
\text { deformed } \\
\text { calves }\end{array}$ & $\begin{array}{c}\text { Management } \\
\text { factors initiating } \\
\text { poisoning }\end{array}$ & $\begin{array}{l}\text { Lupine(s) } \\
\text { present }\end{array}$ & Solution(s) ${ }^{b}$ \\
\hline $\begin{array}{l}\text { Kootenay } \\
\text { District, } \\
\text { BC, } \\
\text { Canada }\end{array}$ & $\begin{array}{l}1989 ; \\
1991-1994\end{array}$ & 200 & 4 & $\begin{array}{l}\text { Cattle exposed to lupine } \\
\text { during critical period }\end{array}$ & $\begin{array}{l}\text { Velvet and } \\
\text { silky }\end{array}$ & $\begin{array}{l}\text { Producer no longer } \\
\text { grazes this pasture } \\
\text { during the critical } \\
\text { period }\end{array}$ \\
\hline $\begin{array}{l}\text { Miami } \\
\text { County, } \\
\text { KS }\end{array}$ & 2000 & $\begin{array}{l}10 \\
\text { embryo- } \\
\text { recipient } \\
\text { heifers }\end{array}$ & 40 & $\begin{array}{l}\text { Expensive embryo- } \\
\text { recipient heifers exposed } \\
\text { to lupine during critical } \\
\text { period; economic loss } \\
\text { high because of the } \\
\text { value of the offspring }\end{array}$ & Silvery & $\begin{array}{l}\text { Change grazing to } \\
\text { eliminate exposure to } \\
\text { lupine during critical } \\
\text { period }\end{array}$ \\
\hline
\end{tabular}

Note: Crooked calf incidents have also been reported in 1994 in Teton County, Montana (13) and in 1999 in Yellowstone County, Montana (14) but the data are incomplete and not included here.

a Location numbers refer to counties in the northwestern United States shown in Figure 3.

b Solutions are either management adjustments made by the livestock producers to reduce losses in subsequent years, or alternatively, adjustments that the producer could make to reduce the risk of calf losses in future years.

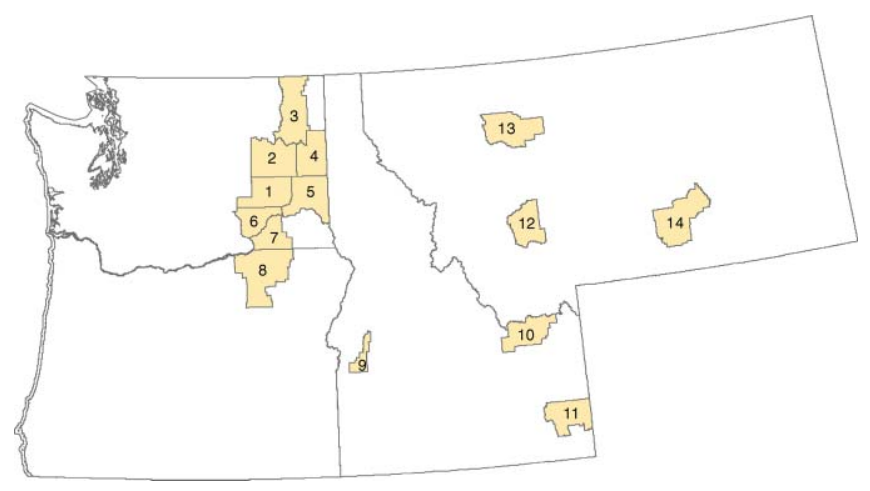

Figure 3. Map of the northwestern United States showing counties that have reported crooked calf incidents in the last $20 \mathrm{yr}$.

Cattle producers in this area have employed several management strategies to minimize the incidence of crooked calves. Some producers have changed to fall calving, while other producers only graze their lupine-infested pastures during the winter months. One producer utilizes herbicide to control the lupine, while another producer keeps his heifers in a feedlot for the first $120 \mathrm{~d}$ of gestation before turning them out to pasture and to calve. Other producers only graze steers on pastures heavily infested with lupine, while some have completely abandoned problematic pastures. These producers are using strategies that minimize the grazing of lupine when anagyrine concentrations in lupines are greatest and during 40-100 d of pregnancy.

A second case in Oregon's Umatilla County (Location 8; Table 2) merits further comment as well. Large calf losses ${ }^{10}$ occurred in Umatilla County during 1991 and 1992. Two

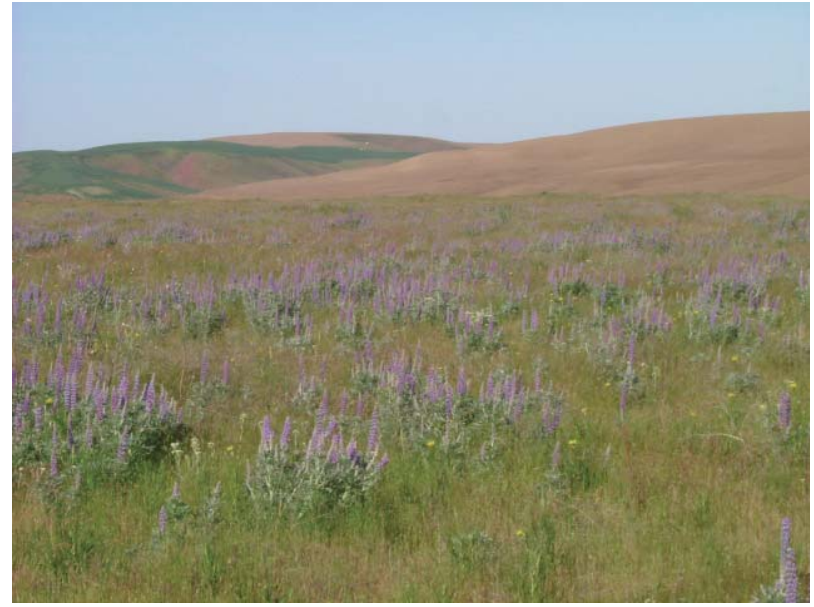

Figure 4. Rangeland in Adams County, Washington, with L. leucophyllus in full flower.

lupine species common to this area were identified as velvet lupine and sulphur lupine. Velvet lupine did not contain anagyrine, whereas the sulphur lupine did contain this toxic alkaloid. Thus, chemical analysis and epidemiological evidence were the key factors demonstrating that sulphur lupine was the species causing the large calf losses in Umatilla County.

The case in Umatilla County demonstrates that cows bred for fall calving may be at risk during unusual years, especially if the cows are bred to calve in late fall (e.g., November). The early spring-like conditions during January and February 1992 caused the lupine to grow and mature earlier than usual, providing pregnant cows with access 


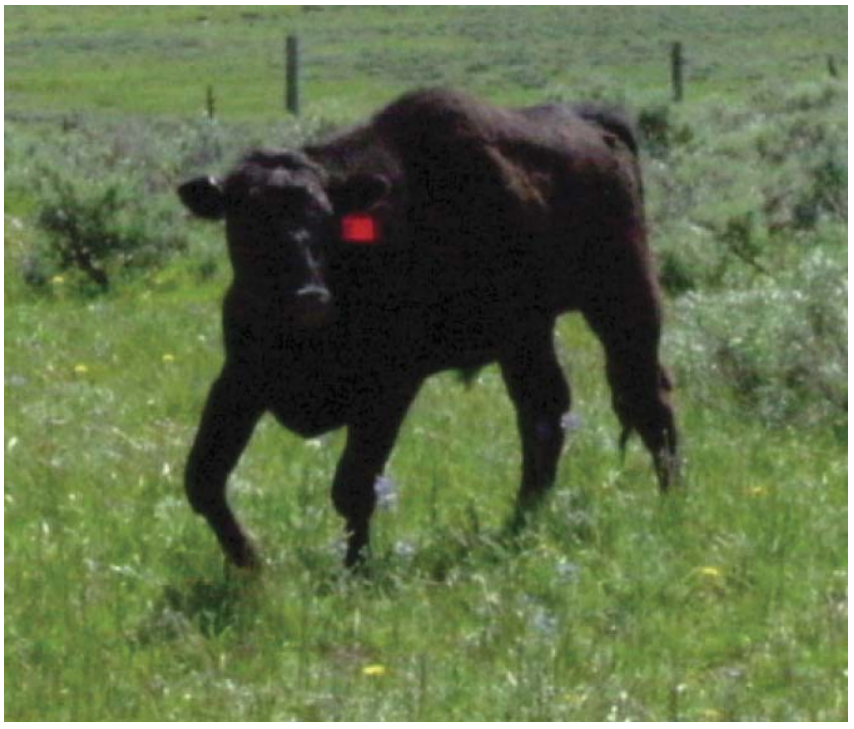

Figure 5. Yearling steer showing crooked legs, neck, and spine typical of lupine-induced crooked calf disease born in 2003 to a cow grazing lupine infested rangelands in Caribou County, Idaho.

to toxic sulphur lupine with seed pods during the critical 40-100-d period following conception. If these cows had been bred to calve earlier in the fall, such as September and October, the likelihood that this critical period of fetal development would overlap with consumption of lupine seed pods would be rare.

\section{Management Recommendations}

1) Identify the lupine species and obtain a chemical analysis of suspect species to determine if calves of pregnant cattle are at risk for crooked calf disease. Not all lupines contain these toxic alkaloids. Standard chemical analysis for these toxins can be provided by the senior author upon request.

2) Be aware of lupine populations on ranges from year to year. Populations fluctuate depending upon winter and spring weather, with risk being greater when lupine population densities are high.

3) Manage breeding so that pregnant cows are not allowed to graze in pastures containing toxic lupines during 40-100 d of pregnancy.

4) Consider changing to a fall calving schedule (SeptemberOctober). With a fall calving schedule toxins are generally not available during the critical $40-100 \mathrm{~d}$ of pregnancy. This decision must be made after consideration of risk and costs of crooked calf disease along with other management decisions affecting the total ranch enterprise, and the possibility of reducing the longevity of some cows within the breeding herd.

5) Graze lupine-containing pastures with stockers or open heifers. Lupine is a nutritious late season feed and a good soil builder.

\section{Summary}

Many of the incidences report only calves that are destroyed. In our experience, there are substantial numbers of affected calves with minor to moderate leg deformities that eventually recover, and perform adequately in the feedlot with minor growth retardation. The real economic losses are not only calf deaths. Costs due to dystocia, caesarian sections, cow deaths, and added veterinary care are also significant. In many cases, lupine-infested pastures are abandoned or grazing is restricted so that potential forage is lost, and other forage must be purchased, thus adding to the economic toll. The emotional strain on humans from crooked calf losses and expenses is also substantial but difficult to quantify for both individual ranch families and their associated communities. Many ranchers that contributed to this report related the emotional stress they felt in anticipating the birth of more deformed calves.

\section{Acknowledgments}

We appreciate the assistance of numerous anonymous ranchers who contributed to this report. We thank Terrie Wierenga, Kermit Price, Andrea Dolbear, and Clint Stonecipher for technical assistance. We appreciate M. E. Barkworth, Director, and K. M. Piep, Assistant Curator, of the Intermountain Herbarium at Utah State University, Logan, Utah, for taxonomic confirmation of plant specimens.

\section{References}

1. Palotay, J. L. 1959. Crooked calves. Western Veterinarian 6:16-20.

2. WAGNON, K. A. 1960. Lupine poisoning as a possible factor in congenital deformities in cattle. Journal of Range Management 13:89-91.

3. Binns, W., And L. F. James. 1961. A congenital deformity in calves, similar to "crooked calf disease" has been experimentally produced by feeding heifers lupine and lead. Proceedings of the Western Section of the American Society of Animal Production 12:1-3.

4. Shupe, J. L., L. F. James, and W. Binns. 1967. Observations on crooked calf disease. Journal of the American Veterinary Medical Association 151:191-197.

5. Shupe, J. L., W. Binns, L. F. James, and R. F. Keeler. 1967. Lupine, a cause of crooked calf disease. Journal of the American Veterinary Medical Association 151:198-203.

6. Panter, K. E., T. D. Bunch, R. F. Keeler, D. V. Sisson, and R. J. Callan. 1990. Multiple congenital contractures (MCC) and cleft palate induced in goats by ingestion of piperidine alkaloid-containing plants: reduction in fetal movement as the probable cause. Clinical Toxicology 28:69-83.

7. Shupe, J. L., W. Binns, L. F. James, and R. A. Keeler. 1968. A congenital deformity in calves induced by the maternal consumption of lupin. Australian Journal of Agricultural Research 19:335-340.

8. Panter, K. E., D. R. Gardner, and R. J. Molyneux. 1998. Teratogenic and fetotoxic effects of two piperidine alkaloidcontaining lupines (L. formosus and L. arbustus) in cows. Journal of Natural Toxins 7:131-140. 
9. Blowey, R., and A. D. Weaver. 2003. Color atlas of diseases and disorders of cattle. 2nd ed. St. Louis, MO, USA: Elsevier/ Mosby Publishing. 272 p.

10. Panter, K. E., D. R. Gardner, C. C. Gay, L. F. James, R. Mills, J. M. Gay, and T. J. Baldwin. 1997. Observations of Lupinus sulphureus-induced "crooked calf disease." Journal of Range Management 50:587-592.

11. Keeler, R. F., and K. E. Panter. 1989. Piperidine alkaloid composition and relation to crooked calf disease-inducing potential of Lupinus formosus. Teratology 40:423-432.

12. Keeler, R. F. 1976. Lupin alkaloids from teratogenic and nonteratogenic lupins. III. Identification of anagyrine as the probable teratogen by feeding trials. Journal of Toxicology and Environmental Health 1:878-889.

13. Panter, K. E., And R. F. Keeler. 1992. Induction of cleft palate in goats by Nicotiana glauca during a narrow gestational period and the relation to reduction in fetal movement. Journal of Natural Toxins 1:25-32.

14. Keeler, R. F., L. F. James, J. L. Shupe, and K. R. Van KAMPEN. 1977. Lupin-induced crooked calf disease and a management method to reduce incidence. Journal of Range Management 30:97-102.

15. Ralphs, M. H., K. E. Panter, C. C. Gay, E. S. MotterRAM, AND S. T. LEE. 2006. Cattle consumption of velvet lupine (Lupinus leucophyllus Dougl.) in the channel scablands of eastern Washington. Rangeland Ecology Eं Management 59: 204-207.

16. Lee, S. T., M. H. Ralphs, K. E. Panter, D. Cook, and D. R. Gardner. 2007. Alkaloid profiles, concentration and pools in velvet lupine (Lupinus leucophyllus) over the growing season. Journal of Chemical Ecology 33:75-84.

17. Panter, K. E., H. F. Maylan, D. R. Gardner, G. Shewmaker. 2001. Beef cattle losses after grazing Lupinuns argenteus (Silvery Lupine). Veterinary and Human Toxicology 43:279-282.

18. Alt, D. 2001. Glacial Lake Missoula. Missoula, MT, USA: Mountain Press. 196 p.
19. Gay, C. C., A. Tibary, K. E. Panter, K. L. Mealey, J. M. Gay, S. W. Hjartarson, E. Motteram, T. Wierenga, and L. F. James. 2007. Lupine-induced crooked calf disease: plasma disposition of lupine alkaloids following repeated challenge in cattle that have given birth to affected calves or those that have borne normal calves. In: K. E. Panter, T. L. Wierenga, and J. A. Pfister [EDs.]. Poisonous plants: global research and solutions. Wallingford, United Kingdom: CABI Publishing. p. 151-155.

20. Gay, C. C., E. S. Motteram, K. E. Panter, and T. Wierenga. 2007. Year-to-year variation in alkaloid concentration in Lupinus leucophyllus growing on the Scablands of central Washington. In: K. E. Panter, T. L. Wierenga, and J. A. Pfister [EDs.]. Poisonous plants: global research and solutions. Wallingford, United Kingdom: CABI Publishing. p. 414-419.

21. Lee, S. T., D. Cook, K. E. Panter, D. R. Gardner, M. H. Ralphs, E. S. Motteram, J. A. Pfister, and C. C. Gay. 2007. Lupine induced "crooked calf disease" in Washington and Oregon: identification of the alkaloid profiles in Lupinus sulphureus, Lupinus leucophyllus, and Lupinus sericeus. Journal of Agricultural and Food Chemistry 55:10649-10655.

Authors are Chemist, stephen.lee@ars.usda.gov (Lee), Toxicologist (Panter, Welch), Rangeland Scientist (Pfister, Ralphs), Chemist (Gardner), Veterinary Pathologist (Stegelmeier), Plant Physiologist (Cook), Pharmacologist (Green), and Biochemist (Davis), Poisonous Plant Research Laboratory, Agricultural Research Service, US Dept of Agriculture, Logan, UT 84341, USA; and Professor Emeritus (Gay) and Research Associate (Motteram), Field Disease Investigation Unit, College of Veterinary Medicine, Washington State University, Pullman, WA 99164, USA. This research was supported by the Utah Agricultural Experiment Station, Utah State University, and approved as journal paper number 7988. 